Mining Engineers of 1930, and they have continued their work practically up to the present. They find that sand between $1 / 10 \mathrm{in}$. and $1 / 100 \mathrm{in}$. is the most effective material, and that a mixture of sand and clay (three of the latter to one of the former) is practically as efficient as sand alone and is much more convenient for stemming horizontal shot holes. To enable the material to be stored without getting dry, the authors recommend 3-5 per cent of calcium chloride to be added, and they state that by the use of a sand and clay stemming, blown-out shots can be prevented, the amount of fumes can be reduced, and up to one third of the cost of the explosives can be saved. From the practical point of view this paper, published at $6 d$. , is of very great value.

\section{The Sir John Cass Technical Institute}

THE Sir John Cass Technical Institute, Aldgate, in the City of London, announces the completion of a new wing adding some seventy-five feet to the frontage of the main building, and providing accommodation for new library and reading rooms, a students' common room, a geology room and museum, and laboratories for metallurgy and pyrometry, assaying and mechanical testing and engraving, and a research laboratory. The new wing is to be opened on October 10 by the Earl of Athlone, Chancellor of the University of London. The Institute provides instruction in pure science as well as in the biochemistry of fermentation, petroleum technology, and fuel technology, in arts and crafts, tailoring and languages, and includes a Nautical School. Sir John Cass, to whose charitable interest in education the Institute owes its origin, was an alderman of the Ward of Portsoken from 1710 until 1718 and sat in Parliament as one of the representatives of the City of London.

\section{Social Hygiene Congress}

A congress of social hygiene will be held at Lyons on October 7-9, with M. Edouard Herriot as president of honour and M. Risler, member of the Institut de France, as president. The following papers among others will be read: Thirty years' campaign against tuberculosis, by Prof. Courmont; the work done by the Rhone Departmental Committee in the campaign against tuberculosis, by Dr. Mouisset; the efforts made on behalf of cheap housing at Lyons, by M. Lévy; the Lyons regional centre and the campaign against venereal diseases, by Prof. Nicolas ; biological and medical foundations for the campaign against infantile mortality, by Prof. Mouriquand; the municipal work for infantile and maternal protection at Lyons, by Drs. Vigne, Trillat and Gardere; the Franco-American foundation for children, its work and results, by Prof. Lepine; the social hygiene centre of the school of nurses and health visitors of Lyons, by Dr. Charles Gardere ; and the work of the anti-cancer centre at Lyons, by Prof. Berard. Further information can be obtained from the general secretary, Prof. Rochaix, 61 rue Pasteur, Lyons, or from Alliance d'Hygiene Sociale, 5 rue Las-Casas, Paris.

\section{Announcements}

By an order of the Committee of Privy Council, the Most Hon. the Marquess of Linlithgow is appointed a member of the Medical Research Council on the retirement of the Right Hon. the Viscount. D'Abernon. Lord Linlithgow will succeed Lord D'Abernon as chairman of the Council.

ON Wednesday, October 3, Prof. G. Barger, professor of chemistry in relation to medicine in the University of Edinburgh, will deliver the inaugural sessional address of the Pharmaceutical Society of Great Britain at its School at 17 Bloomsbury Square, London, W.C.1.

EARCX in 1935, a new international botanical yearbook, to be known as Chronica Botanica, will be published by Fr. Verdoorn, P.O. Box 8, Leyden, Holland. The journal will include important dates of the past, present and future of interest to botanists ; announcements and reports of the International Botanical Congress, and other international societies, congresses, etc.; elections of officers and the reports of botanical societies ; a survey of pure and applied botany during the previous year; and correspondence.

"How to Use a Medical Library" is the title of a booklet by Leslie T. Morton, assistant in the library of the Royal Society of Medicine (London: John Bale, Sons and Danielsson, Ltd., 2s. 6d. net). It should prove a useful guide for research workers and others to the sources of information respecting medical literature and the compilation of medical bibliographies. A list of the principal medical indexes and abstracting journals is included, together with an account of the facilities afforded in medical libraries in Great Britain.

Applications are invited for the following appointments, on or before the dates mentioned :- An assistant for work on electrical equipment for aircraft in the Directorate of Technical DevelopmentThe Chief Superintendent, Royal Aircraft Establishment, South Farnborough, Hants (Oct. 3). An assistant investigator of coal measure strata, in the Safety in Mines Research Board-The UnderSecretary for Mines, Establishment Branch, Mines Department, Cromwell House, Dean Stanley Street, London, S.W.1 (Oct. 6). A mechanical engineer in the Department of the Chief Officer, London Fire Brigade-The Clerk of the Council, County Hall, Westminster Bridge, S.E.l (Oct. 15). A permanent advisory economist at Seale-Hayne Agricultural College, Newton Abbot, Devon-The Secretary. A head of the Department of Mechanical Engineering at the Municipal Technical School, Gamble Institute, St. Helens-The Secretary for Education, Education Office, St. Helens. A teaching scholar in the Department of Botany, University of Birmingham-The Secretary. A technical assistant in the Department of Economics, South Eastern Agricultural College, Wye, Kent-The Secretary. 